\title{
Removal of Phenol and Selected Anions from Refinery Wastewater Using Activated Carbon from Selected Agrowastes
}

\author{
Okereke J. N., Iloegbunam C. A.
}

\begin{abstract}
Refinery wastewater was treated with activated carbon from rice husk (ARH) and corn cob (ACC) using batch method. Agrowastes were carbonized at $6000 \mathrm{C}$ and chemically activated, using phosphoric acid (H3PO4) and used as adsorbents. Titrimetric and spectrophotometeric methods were adopted for the determination of phenol, and some anions (Phosphate, Nitrate - Nitrogen, Sulphate and pH) of refinery wastewater. Readings after treatment with the adsorbents were also recorded and the efficiencies of the adsorbents compared, to ascertain the dose at which purification was best achieved. Initial phenol concentration of $315.9 \mathrm{mg} / \mathrm{l}$ was reduced to $159.0 \pm 48.0-276.5 \pm 46.0 \mathrm{mg} / \mathrm{l}(\mathrm{ARH}), \mathbf{1 5 4 . 7} \pm 50,0-260.2 \pm 53.0$ $\mathrm{mg} / \mathrm{l}(\mathrm{ACC})$ and 132.5 \pm 21.0 - 201.9 $\pm 1.0 \mathrm{mg} / \mathrm{l}(\mathrm{ARH}+\mathrm{ACC})$. The efficiencies of the activated carbon were of the order: Rice husk + corn cob > rice husk > corn cob, while the corresponding dose efficiencies was: $15 \mathrm{~g}>10 \mathrm{~g}>5 \mathrm{~g}$. The highest adsorption efficiency observed for anions were COD $(49.15 \%$ by corn cob), BOD, $(49.4 \%$ by corn cob), phosphate, $(68.18 \%$ by Rice husk + corn cob), nitrate $(\mathbf{7 0 . 6 8 \%}$ by rice husk) and sulphate $(56.68 \%$ by corn cob). Efficiency removal was in this order: Rice husk + corn cob $>$ corn cob $>$ rice husk and $15 \mathrm{~g}>10 \mathrm{~g}>5 \mathrm{~g}$ for the dosage. There was significant difference $(p \leq 0.05)$ between the untreated and the treated refinery wastewater samples and a significant difference also exists between the adsorbents. Findings herein showed that activated rice husks and corn cobs are effective in adsorbing phenol and selected anions in refinery wastewater.
\end{abstract}

Index Terms - Activated Carbon, Agrowastes, Carbonization, Refinery wastewater.

\section{INTRODUCTION}

Among the many cases of pollution of the aqueous medium, is the contamination of water by phenol and heavy metals when a wide range of chemical products are discharged directly or indirectly into the water body without adequate treatment to remove and degrade these harmful compounds. Petroleum refineries use relatively large volumes of water, especially for cooling systems. Surface water runoff and sanitary wastewaters are also generated. The quantity of wastewaters generated and their characteristics depend on the process configuration. As a general guide, approximately $3.5-5.0$ cubic meters $(\mathrm{m})$ of wastewater per ton of crude are generated when cooling water is recycled. Refineries generate polluted wastewaters with biochemical oxygen demand (BOD) and chemical oxygen demand (COD) levels of approximately 150-250 milligrams per liter (mg/l) and

Okereke J. N., Department of Biotechnology, School of Biological Sciences, Federal University of Technology, Owerri, Nigeria

Iloegbunam C. A., Department of Biotechnology, School of Biological Sciences, Federal University of Technology, Owerri, Nigeria
300-600 mg/l, respectively; phenol levels of 20-200 mg/l, oil levels of 100-300 mg/l, and other pollutants (Coelho et al., 2006). Effluent from the petroleum industry mostly have high concentrations of organic and inorganic chemicals and is characterized by high Chemical Oxygen Demand (COD), Biological Oxygen Demand (BOD), Total Dissolved Solids (TDS), pH, Total Suspended Solids (TSS), as well as strong colour. However, wastewater from the petroleum industry is a complex mixture of many polluting substances ranging from residual hydrocarbon to heavy metals associated with the refinery processes. Their disposal is always a matter of great concern because they are considered as dangerous source of pollution of the environment.

The release of phenol into the environment has been a worldwide problem. This is mostly present in wastewater of chemical industries. They are soluble in aquatic environment and can be easily absorbed by living cells. Thus, by entering the food chain, they can be bioaccumulated and biomagnified in higher trophic levels (Malik et al., 2010). Phenol causes adverse effects on public health and environment. Phenolic compounds are very harmful even at very low concentrations due to their toxic and carcinogenic properties. Phenol is designated as the 11th of the 126 priority pollutants by the United States Environmental Protection Agency.

Removal of phenol from the environment is an important challenge. Wastewater treatment processes include precipitation, membrane filtration, ion exchange, adsorption, and distillation (Ahn et al., 2009; Xiong et al., 2009) etc. Studies on the treatment of effluent containing phenol have revealed adsorption to be a highly effective technique for the removal of organic compounds from waste stream (Chand et al., 2004). However, the shortcomings of most of these methods are high operational and maintenance costs, generation of toxic sludge and complicated procedure involved in the treatment (Bhatnagar \& Sillanpaa, 2015). Adsorption is a very effective process for a variety of applications, and is considered economical and widely applicable. It creates relatively little sludge and is an efficient method for metal and phenol removal from wastewaters (Alinor \& Nwachukwu, 2012). Adsorption is a process in which a substance (adsorbate), in gas or liquid phase, accumulates on a solid surface (adsorbent). It is based on the capability of porous materials with large surfaces to selectively retain compounds on the surface of the solid (adsorbent).The adsorption process of the adsorbate molecules from the bulk liquid phase into the adsorbent surface is presumed to involve mass transfer of the adsorbate 
molecules across the external boundary layer towards the solid particle, adsorbate molecules transport from the particle surface into the active sites by diffusion within the pore filled liquid and migrate along the solid surface of the pore, solute molecules adsorption on the active sites on the interior surfaces of the pores, and migration to the pore surface through surface diffusion.

The extent of adsorption also depends on the nature of the solid surface (adsorbent) especially its porosity and surface area. As such, various adsorbents that has high porosity and large surface area have been developed. The porous structure does not only enhance the increase in surface area thereby facilitating adsorption, it also affects the kinetics of the adsorption. Thus, for a good adsorbent, it must have a large surface area and requires less time for adsorption equilibrium (Okereke et al., 2016).The most generally used solid adsorbent is activated carbon, which is used as a very efficient solid adsorbent in many different applications.

Furthermore, the increased awareness of the importance of the current extensive environmental strategies for wastewater treatment has pushed the research community towards the development of agricultural byproducts, economically feasible and environmentally friendly processes, capable of removing pollutants from water and at same time, safeguard the health of affected populations (Lofrano, 2012). By-products from agricultural, domestic and industrial sectors have been recognized as a sustainable solution for wastewater treatment. They allow achieving the removal of pollutants from wastewater and at same time contribute to the waste minimization. Agro-wastes that have been used in wastewater treatment include sugarcane bagasse, groundnut husk, rice husk, sawdust (Jimoh et al., 2015); coconut husk, palm leaf, neem bark, orange peels, maize cob, banana peels (Okereke et al., 2016). Others that have been studied are: Black gram husk (Saeed \& Iqbal, 2003), Waste tea, Turkish coffee, Walnut shell, Papaya wood (Saeed et al., 2005), maize leaf, teak leaf powder (King et al., 2006), Coraindrum sativum (Karunasagar et al., 2005), lalang (Imperata cylindrica) leaf powder (Hanafiah et al., 2007), peanut hull pellets (Johnson et al., 2002), sago waste (Quek et al., 1998), saltbush (Atriplex canescens) leaves (Sawalha et al., 2007). All these materials provide alternative to conventional sources, serving as prospective raw materials for activated carbon production (Mohd-Din et al., 2009).

The benefits of using agricultural wastes for wastewater treatment include easy technique, modest processing, high adsorption ability, selective adsorption of heavy metal ions, economical, availability and easy regeneration. In recent years, attention has been focused on the utilization of unmodified or modified rice husk as an adsorbent for the removal of pollutants. Batch studies using tartaric acid-modified rice husk as adsorbent, have been carried out for the removal of lead and copper and have reported the effects of various parameters such as $\mathrm{pH}$, initial concentration of adsorbate, particle size, temperature etc. Therefore, there is a systemic need that all possible sources of agro-waste adsorbents should be explored and their feasibility such as rice husk and corn cob char for the removal of phenol heavy mental which will be studied in detail in these research.
In the oil sector particularly the refineries; the problem of phenol and some inorganic anions when continuously discharged, will produce significant toxic impact on aquatic environment. The use of conventional approach in the treatment of petroleum wastewater has not been able to solve the problem of phenol which when discharged into the environment has generated environmental hazards particularly to aquatic ecosystem. The use of agro-waste in the treatment of industrial effluent has gained scientific relevance considering the level of successes achieved. The amount of money spent by refineries to reduce the level of phenol in their effluent is enormous and success achieved by using any biosorbent shall be a great financial relief. Thus, this work considered using activated carbon from selected agro-wastes such as rice husk and corn cob to remove phenol and in petroleum refinery wastewater.

Several conventional methods available for treating phenol-laden wastewater include reverse osmosis, anaerobic processes, the electro Fenton method, combined applications of flotation and coagulation processes, stripping and oxidation, solvent extraction etc (Alinor \& Nwachukwu, 2012). Among various methods used in phenol-laden wastewater treatment, 'adsorption' process is considered better due to its simplicity of design, ease of operation and convenience.

Aim of study:To determine the effectiveness of rice husk and corn cob in the removal of phenol and selected anions and heavy metals in petroleum wastewater

\section{Objectives:}

- To determine phenol concentration of petroleum wastewater before and after treatment with adsorbents

- To determine anion properties (Phosphate, Nitrate Nitrogen, Sulphate and $\mathrm{pH}$ ) of petroleum wastewater before and after treatment with adsorbents.

- To compare the efficiencies of the adsorbents.

- To ascertain the concentration at which purification is best achieved.

\section{MATERIALS AND METHODS}

Materials: Rice husk, corn cob, flat bottom flask, graded cylinder, conical flask filter paper, test tubes and oven.

Collection of Sample: Refinery wastewater samples used for this research were collected from Port Harcourt Refinery Company Alesa Eleme, Rivers State, Nigeria, using 1litre plastic Can during morning hours.

Carbonization and activation of absorbent: The method of Grigis \& El-Hendawy (2002) was adopted with slight modification as follows: $750 \mathrm{~g}$ of each agro-waste was washed with de-ionized water, dried and crushed using locally made grinder. They were carbonized in electric muffle furnace at $600^{\circ} \mathrm{C}$ for $45 \mathrm{~min}$. The carbonized sample was sieved using $1.18 \mathrm{~mm}$ mesh. Activation was achieved by mixing the carbonized sample with $20 \% \mathrm{H}_{3} \mathrm{PO}_{4}$ solution at a ratio of 1:1 (Acid: Char) and stirred for $30 \mathrm{~min}$. After that, the sample was filtered, washed with de-ionized water until the washed off water gave a $\mathrm{pH}$ of 7.0. Washed activated carbon was then dried at $120^{\circ} \mathrm{C}$ in an oven. The dried sample was 
stored in airtight plastic container.

Batch studies: The influence of various experimental parameters such as $\mathrm{pH}$ and adsorbent dosage on the adsorption of phenol, lead, zinc, iron, phosphate, nitrate and sulphate, COD and BOD were optimized in a batch mode of studies. The concentrations of different ground, fine powder of the adsorbent were $5 \mathrm{~g}, 10 \mathrm{~g}$ and $15 \mathrm{~g}$. Each was mixed with $500 \mathrm{ml}$ of the wastewater. The sample was poured inside round bottom conical flask and stirred at 140rpm speed using rotary shaker at room temperature to obtain homogenous mixture for 2hour. It then was allowed to settle for 14 hours and filtered using whatman no.1 filter paper to remove the bio sorbent precursors. The treated effluent was then analysized.

\section{Characterization of Wastewater}

Phenol determination (APHA, 2013)

Phenol $(0.5 \mathrm{ml})$ diluted to $100 \mathrm{ml}$, was placed in a $250 \mathrm{ml}$ beaker. Then, $100 \mathrm{ml}$ distilled water blank, and series of 100 $\mathrm{ml}$ phenol standards containing $0.1,0.2,0.3,0.4$, and $0.5 \mathrm{mg}$ phenol were prepared. Sample, blank, and standards were treated as follows: $2.5 \mathrm{ml} 0.5 \mathrm{~N} \mathrm{NH}_{4} \mathrm{OH}$ solution added, and immediately adjusted to $\mathrm{pH} 7.9 \pm 0.1$ with phosphate buffer. Thereafter, $1.0 \mathrm{ml}$ 4-aminoantipyrine solution was added and mixed well. Again, $1.0 \mathrm{ml} \mathrm{K}_{3} \mathrm{Fe}(\mathrm{CN})_{6}$ solution was added and mixed. After $15 \mathrm{~min}$, the absorbance of samples and standards against the blank were read using spectrophotometer at $500 \mathrm{~nm}$. Phenol values were calculated using the equation:

\section{X D X 100}

$\mathrm{phenol} / \mathrm{L}=$

\section{E}

Where: $\mathrm{C}=\mathrm{ml}$ of standard phenol solution, $\mathrm{D}=$ absorbance of sample, and

$\mathrm{E}=$ absorbance of standard phenol solution.

pH: $\mathrm{pH}$ was determined by taking the $\mathrm{pH}$ readings before and after treatment of the wastewater using $\mathrm{pH}$-meter. It was first calibrated with a buffer of 7.0.

Phosphate (Ascorbic Acid Method): Wastewater sample $(50 \mathrm{ml})$ was pipetted into an acid-cleaned, dry $125 \mathrm{ml}$ Erlenmeyer flask and a drop of phenolphthalein indicator added. When red color developed, $8 \mathrm{ml}$ of $5 \mathrm{~N}$ sulfuric acid was added until the color disappeared. The mixture was allowed at least 10 minutes (but not more than 30 minutes) for color development. Absorbance at $880 \mathrm{~nm}$ was measured using a reagent blank to zero the spectrophotometer. The final concentration of phosphate was determined using the following equation: $\mathrm{Mg} / \mathrm{l} \mathrm{P}=\mathrm{mg} / \mathrm{l}$ from the curve $\mathrm{x} 50 \mathrm{ml}$ divided by initial volume used (ml).

Nitrate - Nitrogen (Colorimetric Method): The wastewater sample was passed through a copper-coated Cadmium reduction column. Nitrate in the sample was reduced to nitrite in a buffer solution. The nitrite was then determined by diazotizing with sulfanilamide and coupling with N-1-naphthylethylenediamine dihydrochloride to form acolorazo dye. The absorbance was measured at $540 \mathrm{~nm}$ which is linearly proportional to the concentration of nitrite + nitrate in the sample. Nitrate concentrations were obtained by subtracting nitrite values, which have been separately determined without the cadmium reduction procedure, from the nitrite + nitrate values.

Sulphate (Turbidometric Method): De-ionised water $(100 \mathrm{ml})$ was poured into a clean and acid-washed beaker with $50 \mathrm{ml}$ of buffer solution, and then transferred into a clean, 125 $\mathrm{ml}$ Erlenmeyer flask containing a clean magnetic stirring bar. Some $10 \mathrm{ml}$ of deionised water, $6 \mathrm{ml}$ of buffer reagent, and $10 \mathrm{ml}$ of the standard solution were added into the flask. It was swirled gently to ensure mixing. About $0.1 \mathrm{~g}-0.2 \mathrm{~g}$ of $\mathrm{BaCl}_{2}$ was added to the flask which was immediately placed on the magnetic stirrer and stirred for 58 to 62 seconds. After a minute of stirring, the solution was allowed to stand undisturbed for $\sim 2$ minutes. The absorbance was measured by a spectrophotometer at the wavelength of $420 \mathrm{~nm}$ and sulphate concentration determined by comparison of the reading with a standard curve.

\section{Efficency of Activated Carbon}

The efficiency $(\%)$ of activated carbon was calculated according to Ahmad et al. (2016) as:

$$
\text { Efficiency }=\frac{\mathrm{C}_{\mathrm{o}}-\mathrm{C}_{\mathrm{k}}}{\mathrm{C}_{\mathrm{o}}} \times 100
$$

Where: $C_{o}=$ Initial concentration of parameter; $C_{k}=$ concentration of parameter after treatment

Statistical Analysis: Student t- test and ANOVA at 95\% confident levels were used to analyze data obtained.

\section{RESULTS}

\section{Phenol Removal in Refinery Wastewater Using Activated Carbon}

Table 1 shows the results of phenol concentrations in refinery wastewater treated with activated carbon from rice husk (ARH), corncob (ACC) and combination of rice husk and corncob (ARH + ACC). A decline from the initial phenol concentration after treatment with the adsorbents was observed. After treatment, phenol concentration ranged from $159.0 \pm 48-276.5 \pm 46 \mathrm{mg} / \mathrm{l}(\mathrm{ARH}), 154.7 \pm 50-260.2 \pm 53 \mathrm{mg} / \mathrm{l}$ (ACC) and 132.5 $\pm 21-201.9 \pm 1 \mathrm{mg} / \mathrm{l}(\mathrm{ARH}+\mathrm{ACC})$. There was a significant $(\mathrm{P}<0.05)$ difference between untreated and the treated wastewater.

Chemical properties of refinery wastewater treated with activated carbon from agrowastes

Table 2 shows the results for the concentrations of anions in untreated and treated refinery wastewater. General decline in anion concentrations was observed after treatment. ACC $(15 \mathrm{~g})$, best reduced Chemical Oxygen Demand (COD), Biochemical Oxygen Demand (BOD), phosphate $\left(\mathrm{PO}_{4}{ }^{3-}\right)$ and sulphate $\left(\mathrm{SO}_{4}{ }^{2-}\right)$ while ARH $+\mathrm{ACC}(5 \mathrm{~g})$, best reduced nitrate $\left(\mathrm{NO}_{3}{ }^{-}\right)$. A significant $(\mathrm{P}<0.05)$ difference existed between untreated and treated wastewater.

Removal Efficiency of Phenol in refinery wastewater

Fig 1 shows the removal efficiency (\%) of phenol from refinery wastewater by activated carbon from rice husk $(\mathrm{ARH})$, corncob (ACC) and combination of rice husk and corncob (ARH + ACC). Reduction efficiencies of phenol by 
$5 \mathrm{~g}$ of ARH, ACC and ARH+ACC were $12.47 \%, 17.63 \%$ and $36.09 \%$ respectively. Efficiency of $10 \mathrm{~g}$ of the activated carbon were $26.72 \%(\mathrm{ARH}), 20.89 \%$ (ACC), and $17.44 \%$

Table 1: Phenol level in Refinery Wastewater treated with different doses of activated carbon

\begin{tabular}{|c|c|c|c|}
\hline Parameter & $\begin{array}{l}\text { Phenol } \\
(\mathrm{mg} / \mathrm{l})\end{array}$ & & \\
\hline & $5 g$ & $10 \mathrm{~g}$ & $15 \mathrm{~g}$ \\
\hline ARH & $276.5 \pm 46.0$ & $231.5 \pm 10.0$ & $159.0 \pm 48.0$ \\
\hline $\mathrm{ACC}$ & $260.2 \pm 53.0$ & $249.9 \pm 55.0$ & $154.7 \pm 50.0$ \\
\hline$A R H+A C C$ & $201.9 \pm 1.0$ & $260.8 \pm 44.0$ & $132.5 \pm 21.0$ \\
\hline UT & $315.9 \pm 5.5$ & & \\
\hline
\end{tabular}

All values were expressed as Mean \pm STDEV (Standard deviation).

UT - untreated refinery wastewater; ARH- refinery wastewater treated with activated rice husk; ACC - refinery wastewater treated with activated corncob; ARH+ACC - refinery wastewater treated with activated rice husk and corn cob.

Table 2: Chemical properties of refinery wastewater treated with activated carbon

\begin{tabular}{|c|c|c|c|c|c|c|c|}
\hline Parameters & & COD (mg/l) & BOD (mg/l) & $\mathrm{PO}_{4}{ }^{3-}(\mathrm{mg} / \mathrm{l})$ & $\mathrm{NO}_{3}{ }^{-}(\mathrm{mg} / \mathrm{l})$ & $\mathrm{SO}_{4}{ }^{2-}(\mathrm{mg} / \mathrm{l})$ & $\mathrm{pH}$ \\
\hline \multirow[t]{2}{*}{ UT } & & $1762.2 \pm 1.0$ & $634.4 \pm 0.1$ & $7.07 \pm 1.0$ & $39.22 \pm 1.0$ & $572.2 \pm 2.1$ & $7.59 \pm 0.6$ \\
\hline & $5 g$ & $960.0 \pm 1.0$ & $350.7 \pm 0.6$ & $6.92 \pm 0.6$ & $11.4 \pm 0.6$ & $468.4 \pm 1.1$ & $7.45 \pm 0.6$ \\
\hline \multirow[t]{3}{*}{$\mathrm{ARH}$} & $10 \mathrm{~g}$ & $952.1 \pm 2.0$ & $353.8 \pm 0.5$ & $6.89 \pm 0.4$ & $11.2 \pm 1.0$ & $460.3 \pm 1.1$ & $7.44 \pm 0.6$ \\
\hline & $15 \mathrm{~g}$ & $925.9 \pm 0.5$ & $333.3 \pm 1.0$ & $6.10 \pm 0.6$ & $11.5 \pm 0.5$ & $459.3 \pm 0.9$ & $7.43 \pm 1.0$ \\
\hline & $5 g$ & $901.2 \pm 1.0$ & $327.8 \pm 0.5$ & $4.50 \pm 0.6$ & $28.9 \pm 0.7$ & $249.5 \pm 0.6$ & $7.58 \pm 0.6$ \\
\hline \multirow[t]{3}{*}{ ACC } & $10 \mathrm{~g}$ & $899.5 \pm 0.6$ & $328.9 \pm 0.5$ & $4.41 \pm 0.1$ & $30.2 \pm 1.0$ & $482.3 \pm 0.9$ & $7.54 \pm 0.6$ \\
\hline & $15 \mathrm{~g}$ & $896.1 \pm 1.0$ & $322.7 \pm 0.5$ & $4.39 \pm 0.6$ & $37.8 \pm 0.6$ & $247.4 \pm 0.6$ & $7.53 \pm 0.6$ \\
\hline & $5 g$ & $960.2 \pm 1.0$ & $349.8 \pm 0.5$ & $5.88 \pm 0.6$ & $10.5 \pm 0.5$ & $438.2 \pm 1.1$ & $7.41 \pm 0.5$ \\
\hline \multirow[t]{2}{*}{$\mathrm{ARH}+\mathrm{ACC}$} & $10 \mathrm{~g}$ & $950.1 \pm 1.0$ & $349.5 \pm 0.6$ & $5.79 \pm 0.6$ & $10.8 \pm 2.1$ & $437.9 \pm 0.5$ & $7.41 \pm 0.5$ \\
\hline & $15 \mathrm{~g}$ & $955.8 \pm 0.5$ & $344.1 \pm 2.7$ & $5.73 \pm 0.6$ & $10.9 \pm 1.0$ & $435.6 \pm 0.6$ & $7.39 \pm 0.6$ \\
\hline
\end{tabular}

EPA limits

$3600-5300 \quad 300-500 \quad 10$

20

500

6-9

All values were expressed as Mean \pm STDEV (Standard deviation).

UT - untreated refinery wastewater; ARH- refinery wastewater treated with activated rice husk; ACC - refinery wastewater 
treated with activated corncob; ARH+ACC - refinery wastewater treated with activated rice husk and corn cob.

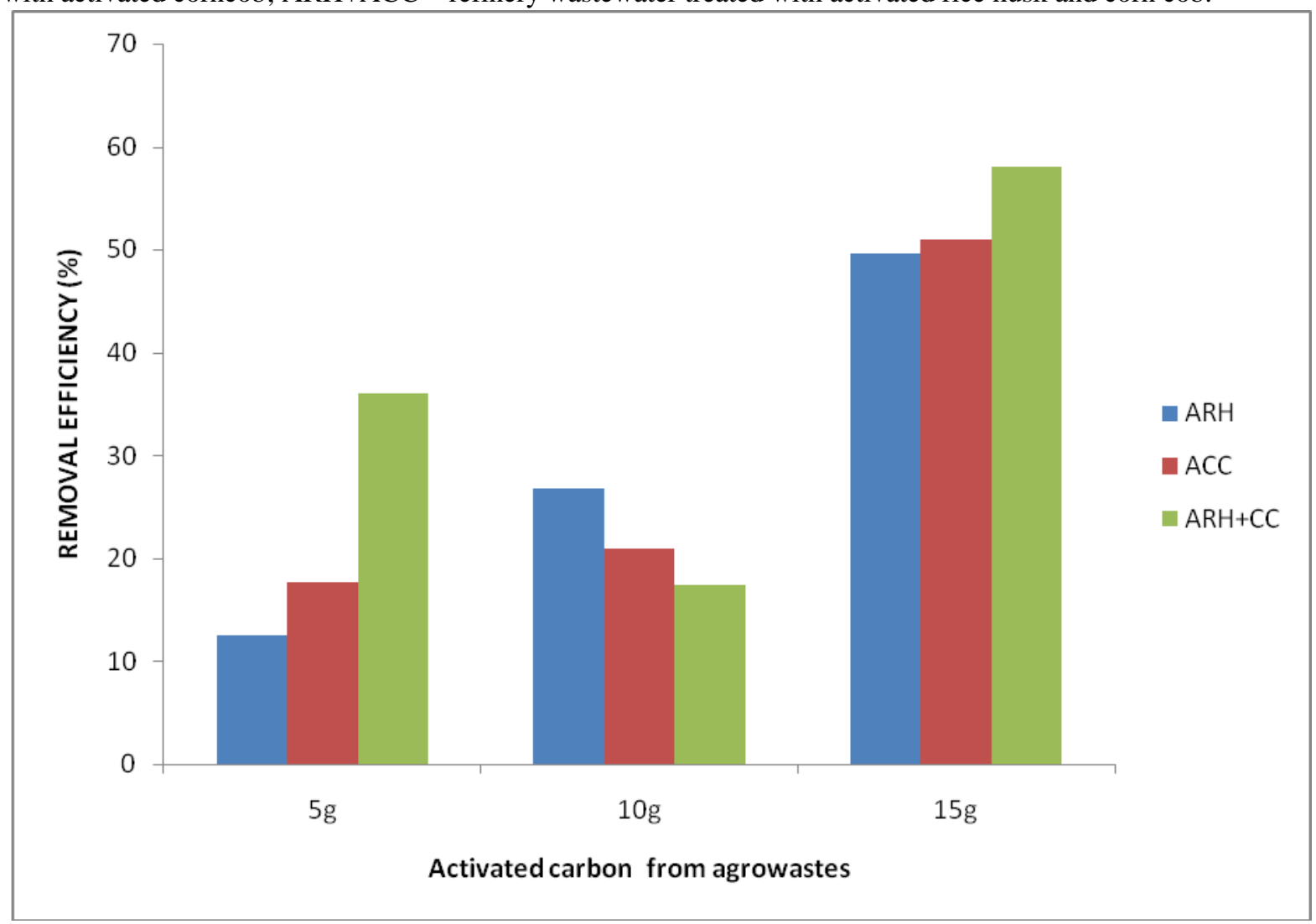

Fig 1: Efficiency of activated carbon in removing Phenol in refinery wastewater

ARH - refinery wastewater treated with activated rice husk; ACC - refinery wastewater treated with activated corncob; $\mathrm{ARH}+\mathrm{ACC}$ - refinery wastewater treated with activated rice husk and corn cob.

Reduction Efficiency of some chemical properties of treated refinery wastewater

Table 3 shows the reduction efficiency (\%) of some chemical properties of treated refinery wastewater using activated carbon from rice husk (ARH), corncob (ACC) and combination of rice husk and corncob (ARH + ACC). Reduction efficiency for COD ranged from 45.51\% - 49.14\%; BOD, 44.23\% - 49.14\%; phosphate, 2.12 - 37.91\%; nitrate, 3.67 - 71.44\%; and sulphate, $15.70-56.76 \%$. The $15 \mathrm{~g}$ dose of activated carbon had more adsorption potential followed by $10 \mathrm{~g}$ and $5 \mathrm{~g}$ doses. Performance of the activated carbon was in this order: ARH + ACC $>$ ARH $>$ ACC.

Table 3: Reduction Efficiency of some chemical properties of treated refinery wastewater

$\begin{array}{lllll}\mathbf{5 g} & \begin{array}{l}\text { ARH } \\ (\boldsymbol{\%})\end{array} & \begin{array}{l}\text { ACC } \\ (\mathbf{\%})\end{array} & \begin{array}{l}\text { ARH+ACC } \\ (\boldsymbol{\%})\end{array} \\ & \text { COD } & 45.52 & 48.86 & 45.51 \\ & \text { BOD } & 44.72 & 48.33 & 44.86 \\ & \text { PHOSPHATE } & 2.12 & 36.35 & 16.83 \\ \mathbf{1 0 g} & \text { NITRATE } & 70.93 & 26.31 & 69.32 \\ & \text { SULPHATE } & 18.13 & 56.39 & 23.42 \\ & \text { COD } & 45.97 & 48.96 & 46.09 \\ & \text { BOD } & 44.23 & 48.16 & 44.91 \\ & \text { PHOSPHATE } & 2.55 & 37.62 & 18.10 \\ & \text { NITRATE } & 71.44 & 22.99 & 68.44 \\ & \text { SULPHATE } & 19.55 & 15.70 & 23.47 \\ & \text { COD } & 47.46 & 49.15 & 45.76 \\ & \text { BOD } & 47.46 & 49.14 & 45.76 \\ & \text { PHOSPHATE } & 13.72 & 37.91 & 18.95 \\ & \text { NITRATE } & 70.68 & 3.67 & 68.18 \\ & \text { SULPHATE } & 19.73 & 56.76 & 23.87\end{array}$

ARH- refinery wastewater treated with activated rice husk; ACC - refinery wastewater treated with activated corncob; $\mathrm{ARH}+\mathrm{ACC}-$ refinery wastewater treated with activated rice husk and corn cob. 


\section{DISCUSSION}

According to results obtained, the untreated refinery wastewater contained $315.1 \mathrm{mg} / \mathrm{L}$ of phenol which is far above WHO standard. Phenol at low concentration, causes toxicity and fowl odour in water due to its ability to react with elements (derivatives) (Buah et al., 2016). On the use of different doses of activated carbon forms in removing phenol, it was observed that the highest doses of activated rice husk, corncob and their combination (rice husk and corn cob) performed better at $\mathrm{pH}$ value of 7 . This result is in tandem with the work of Sing et al. (2008), who reported that increase in percentage/quality of adsorbent dose increased phenol removal due to large amount of adsorptive sites available. $\mathrm{pH}$ level helped the adsorption of phenol to carbon. As stated by Salare \& Barndosz (2003), adsorption properties may be influenced by the $\mathrm{pH}$ value of the solution due to the amphoteric character of a carbon surface. This of course, maybe what played out in this study.

The chemical properties such as $\mathrm{pH}$, phosphate, nitrate, sulphate, BOD and COD of the refinery wastewater were above the Environmental Protection Agency (EPA, 2009) permissible limits. Domestic, mining, industrial and agricultural activities and municipal discharges have released phosphate into water bodies in the form of organic and inorganic phosphates. After treatment with the different doses of the activated carbon from agrowastes and their combinations, there was general reduction in the physicochemical properties of the refinery wastewater compared with the control (untreated). Apart from the phosphate, the $15 \mathrm{~g}$ dose of the activated corncob performed better in reducing the assessed parameters than the activated rice husk and their combination. This finding is synonymous with the report of Egdon et al. (2013). Activated carbon from maize cob produced at $2500 \mathrm{C}$ has the ability to treat wastewater due to its unique features such as large surface area, high degree of surface reactivity and better pore size.

Efficiency of activated carbon from different agrowastes in reducing phenol from refinery wastewater was in this order: Rice husk + corn cob > rice husk > corn cob. For the dosage $(\mathrm{g})$, the removal efficiency was in this order: $15 \mathrm{~g}>10 \mathrm{~g}>5 \mathrm{~g}$, as rice husk gave the best adsorption at $10 \mathrm{~g}$ dose. Yan et al. (2013) reported that with increased dosage from 10-15g, removal of phenol increases, thus agreeing with the results obtained in this study. AL-Doury \& Ali (2015) noted that rice husk is a better adsorbent of phenol because the main components of rice which is carbon and silica, in their ionic structures, provide a capability of adsorbing phenolic compounds which are polar molecules.

The highest adsorption efficiency was observed with $15 \mathrm{~g}$ dosage, COD ( $49.15 \%$ by corn cob), BOD ( $49.40 \%$ by corn cob), phosphate $(68.18 \%$ by Rice husk + corn cob), nitrate (70.68\% by rice husk), and sulphate $(56.68 \%$ by corn cob). Efficiency reduction of COD, BOD, phosphate, nitrate and sulphate, was in this order: Rice husk + corn cob > corn cob > rice husk. For the dosage $(\mathrm{g})$, the removal efficiency for the three metals was in this order: $15 \mathrm{~g}>10 \mathrm{~g}>5 \mathrm{~g}$. According to AL-Doury \& Ali (2015), activated carbon from rice husk and corn cob, are good adsorbents. Buah et al. (2010) recorded efficiency reduction of COD and BOD by activated carbon from rice husk as $89 \%$ and $100 \%$ respectively; $78 \%$ and $97 \%$ respectively, for corn cob. Anyikaiye et al. (2019), established the use of above adsorbents to achieve $75-98.3 \%$ removal of Nitrate, and 64.4-85.2\%, of sulphate. All these are synonymous with the findings in this study.

Conclusion: This study has shown that wastewater from refineries are potential pollutants, which could have adverse impact on the quality of the receiving water bodies. Findings herein showed that activated rice husks and corn cobs are effective in adsorbing phenol and reduction of selected anions. A significant difference $(\mathrm{p} \leq 0.05)$ exists between the untreated and treated refinery wastewater with the above mentioned agrowastes (in their activated forms). Significant difference also exists between the adsorbents used in the treatment of the wastewater. It can be concluded that the activated carbon from rice husk and corn cob are good adsorbents for the treatment of refinery wastewater.

\section{REFERENCES}

[1] G Ahmad, H., Ee, C. J. \& Baharadin, N. S. (2016). A preliminary study for removal of heavy metals from acidic synthentic wastewater by using pressmud-rice husk mixtures. International Conference on Chemical Engineering and Bioprocess Engineering: Earth and Environmental Science, 36: 012031.

[2] Ahn, C. K., Kim, Y. M., Woo, S. H. \& Park J. M. (2009). Removal of cadmium using acid-treated activated carbon in the presence of nonionic and/or anionic surfactants. Hydrometallurgy, 99: 209-213

[3] Al-Dowry, M. \& Ali, S. (2015). Removal of phenol and parachlorophenol from synthetic wastewater using prepared activated carbon from agricultural wastes. International Journal of Sustainable and Green Energy, 4(3):93-101.

[4] Alinnor, I. J. \& Nwachukwu, M. A. (2012). Adsorption of phenol on surface-modified cassava peel from its aqueous solution. International Journal of Environmental Science, Management and Engineering, 1(2): $68-74$

[5] APHA, American Public Health Association (2013). Standard methods for the examination of water and wastewater, $20^{\text {th }}$ edn.. American Public HealthAssociation, Washington, DC, USA. pp. 517.

[6] Ayub, S., Ali, S.I., \& Khan, N. (2001). Efficiency evaluation of neem (Azadirachta indica) bark in treatment of industrial wastewater. Environmental Pollution Control Journal, 4 (4):34-38

[7] Bhatnagar, M. \& Sillanpää, A. (2015). Agricultural waste peels as versatile biomass for water purification. Chemical Engineering Journal, 270: 244-271

[8] Buah, W., MacCaarthy, J. \& Ndur, S. (2016). Conversion of corn cob waste into activated carbons for adsorption of heavy metals from minerals processing wastewater. International Journal of Environmental Protection and Policy. 4(4): 98-103.

[9] Chand, S., Aggarwal, V. K. \& Kumar P. (2004). Removal of hexavalent chromium from the wastewater by adsorption. Indian Journal of Enviromental. Health, 36 (3):151-158

[10] Coelho, A., Castro, A.V., Dezotti, M. \& Sant'Annar Jr, G.L. (2006) Treatment of petroleum refinery sourwater by advanced oxidation processes, Journal of Hazardous Materials, 137(1):178-185.

[11] Egdon, E. E., Idodoe, V. O., Egbon, E. I. \& Chukwuma, P. A. (2013). Treatment of saloon waste water using activated carbon. Chemical and Process Engineering Research, 17: 224-7467.

[12] EPA (2009). National Primary Drinking Water Standards, http://water.epa.gov/drink/contaminant/index.cfm\#list.

[13] Girgis, B. S., EI-Hendawy, A. N. (2002). Porosity development in activated carbons obtained from date pits under chemical activation with phosphoric acid. Microporous and Mesoporous Materials, 52:105-117.

[14] Hanafiah, M., Ngah, W. S., Zakaria, H. \& Ibrahim, S. C. (2007). Batch study of liquid-phase adsorption of lead ions using Lalang (Imperatacylindrica) leaf powder. Journal of Biological Scicences, 7: 222-230.

[15] Jimoh, T., Egila, J. N., Dauda, B. E.\& Iyaka Y. A (2011). Agricultural waste as a low cost adsorbent for heavy metal removal from 
wastewater. International Journal of the physical science, 6(8): 2152-2157.

[16] Johnson, P. D., Watson, M. A., Brown, J. \& Jefcoat, I. A. (2002) Peanut hull pellets as a single use sorbent for the capture of $\mathrm{Cu}$ (II) from wastewater. Waste Management, 22: 471-480.

[17] Karunasagar, D., Balarama-Krishna, M. V., Rao, S. V. \& Arunachalam, J. (2005). Removal of preconcentration of inorganic and methyl mercury from aqueous media using a sorbent prepared from the plant Coriandrumsativum. Journal of Hazard Materials, 118: 133-139.

[18] King, P., Srivinas, P., Prasanna, K. Y. \& Prasad, V. S. (2006). Sorption of copper (II) ion from aqueous solution by Tectonagrandisl.f. (teak leaves powder). Journal of Hazardous Materials, 136: 560-566.

[19] Lofrano, G. (2012). Emerging Compounds Removal from Wastewater pringer. Netherlands, 15-37

[20] Malik, N. Biswas, A.K. Qureshi, T.A. Borana, K. Virha R. (2010) Bioaccumulation of phenol in fish tissues of a freshwater lake of Bhopal. Environmental Monitoring Assessment, 160:267-276

[21] Mohd-Din, A. T. Hameed, B. H. \& Ahmad, A. L. (2009) Batch adsorption of phenol onto physiochemical-activated coconut shell. Journal of Hazardous Materials, 161(2-3)1522-1529

[22] Okereke, J. N., Ogidi, O. I. \& Obasi, K. O. (2016) Removal of Inorganic Anions in Brewery Effluent using Banana Peels. International Journal of Advanced Research in Biological Sciences, 3(6): 192-197.

[23] Quek, S. Y., Wase, D. A. \& Forster, C. F. (1998) The use of sago waste for the sorption of lead and copper. Water SA, 24: 251-256.

[24] Saeed, A., Iqbal, M. \& Akhtar, M. W (2005) Removal and recovery of heavy metals rom aqueous solution using papaya wood as a new biosorbent. Separation and Purification Technology, 45: 25-31.

[25] Saeed, A. \& Iqbal, M. (2003) Bioremoval of cadmium from aqueous solution by black gram husk (Cicerarientinum). Water Resources, 37: 3472-3480.

[26] Sawalha, M. F., Peralta-Videa, J. R., Romero-Gonza'lez, J., Duarte-Gardea, M. \& Gardea-Torresdey, J. L. (2007) Thermodynamic and isotherm studies of the biosorption of $\mathrm{Cu}$ (II), $\mathrm{Pb}$ (II), and $\mathrm{Zn}$ (II) by leaves of saltbush(Atriplexcanescens). Journal of Chemical Thermodynamics, 39: 488-492.

[27] Xiong, C., Yao, C., Wang, L. \& Ke. J. (2009). Adsorption behavior of $\mathrm{Cd}$ from aqueous solution onto gel-type weak acid resin. Hydrometallurgy, 98 (2009): 318-324

[28] Yan, M., Nai-Yun, G., Wenhai, C. \& Cong, L. (2013). Removal of phenol by powdered activated carbon. Frontiers of Environmental Science \& Engineering, 7(2):158-165. 